\title{
Dimethyl titanocene Y: A valuable precursor for libraries of cytotoxic titanocene derivatives
}

\author{
Timo A. Immel, Josefine T. Martin, Christoph J. Dürr, Ulrich Groth, Thomas Huhn * \\ Fachbereich Chemie and Konstanz Research School Chemical Biology, Universität Konstanz, Universitätsstrasse 10, Fach 720, 78457 Konstanz, Germany
}

Keywords:

Cytotoxicity

Titaniam complexes

Library-synthesis

Cancer

\begin{abstract}
A B S T R A C T
Reaction of the known titanocene Y 2 with methyl lithium at $-15^{\circ} \mathrm{C}$ yields bis-[(p-methoxybenzyl) cyclopentadienyl]titanium(IV) dimethyl (dimethyl titanocene $\mathrm{Y}, 3$ ), a hitherto unknown, surprisingly robust titanium (IV) dimethyl species. Dimethyl titanocene $Y$ was utilized in the preparation of several bis-[( $p$ methoxybenzyl)cyclopentadienyl|titanium(IV) dicarboxylates by the reaction with the free carboxylic acids in fair to good yields. Cytotoxicity of all new compounds has been estimated in Hela S3 cells.
\end{abstract}

\section{Introduction}

The development of platinum complexes such as cisplatin, carboplatin or oxaliplatin had an enormous impact on current cancer chemotherapy. Unfortunately, the spectrum of cancers treatable with those platinum agents is narrow and treatment is associated with severe dose-limiting side effects and resistance phenomena [1-3] These unsolved problems in platinum-based anti-cancer therapy led to an increased search for novel non-platinum-containing complexes as cytostatic agents [4-10].

Titanium complexes based on the octahedral species budotitane [11-13] or on titanocene dichloride [14-18] showed encouraging antitumor activity in various cell lines and little cross resistance to cisplatin was observed. Titanocene dichloride itself was found to enrich in areas near the nuclear chromatin, inhibit DNA synthesis and induce apoptosis [19-22]. Binding studies suggested that the cellular uptake of titanocene dichloride may be mediated either by the iron transport protein transferrin or by human serum albumin [23-28].

The main disadvantages of these complexes, probably leading to the low activities observed in clinical phase II trials, are their poor solubility in aqueous media and their hydrolytic instability under physiological conditions, ultimately leading to unidentified metabolites $[29,30]$.

Dimethylamino or methoxy derivatization of the cylopentadienyl (Cp) rings proofed to be a valuable concept to improve solubility. One of the most active titanium complexes, bis-[(p-methoxybenzyl)

\footnotetext{
* Corresponding author. Fax: +497531884424

E-mail address: thomas.huhn@uni-konstanz.de (T. Huhn).
}

cyclopentadienyl]titanium(IV) dichloride (titanocene $Y$ ), was thereby found by the Tacke group in 2005 [16]. Concerning hydrolysis, it is believed that the chloride derivative hydrolyses too quickly and is therefore not an optimal candidate for therapeutic use [29]. In order to optimize its biological potential, Claffey et al. derivatized titanocene $Y$ through anion-exchange using silver oxalate [31]. The obtained oxalititanocene $Y$ was found to be 13-fold more cytotoxic against the porcine kidney cell line LLC-PK than titanocene $Y$ itself and twice as active as cisplatin thus making it the most toxic titanocene derivative. Despite this success, the use of silver salts suffers from several disadvantages. The often colloidal silver chloride is hard to filter off and potential contaminations with silver species may distort the outcome of the biological assays. Moreover, for the synthesis of large libraries to systematically study the influence of the non-Cp ligands, silver salts for every compound have to be synthesized.

\section{Experimental}

\subsection{General}

All experiments requiring dry atmosphere were carried out under an atmosphere of dry nitrogen using either standard Schlenk technique or utilizing a MBraun Labmaster MB150 Glovebox. Superhydride (lithium triethylborohydride, $1 \mathrm{M}$ in tetrahydrofuran [THF]) was purchased from Aldrich Chemical Company, methyllithium (2.3 $\mathrm{M}$ in diethyl ether) from Chemetall. All chemicals and solvents were dried and purified when necessary according to standard procedures [32]. NMR spectra were measured on a Bruker Avance DRX 600 spectrometer. Chemical shifts ( $\delta)$ are referenced on the residual proton signals of the solvent and are given in parts per million 
Table 1

Employed dicarboxylic acids for the derivatization of dimethyl titanocene $Y$ and yields of the resulting dicarboxylates.

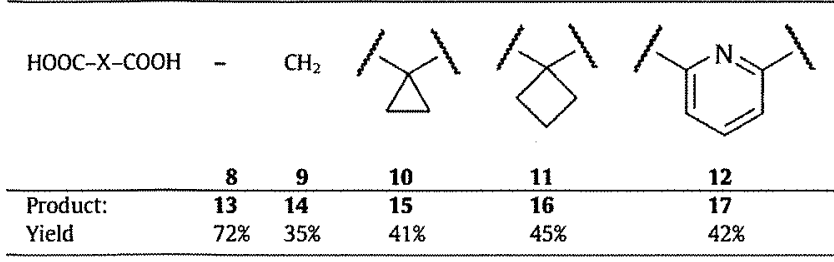

downfield from tetramethylsilan (TMS). Structure assignments were done based on 2D-NMR (correlation spectroscopy [COSY], heteronuclear multiple bond coherence [HMBC], heteronuclear single quantum coherence [HSQC]) experiments. Signal multiplicities are assigned as multiplet $(m)$, singlet $(s)$, dublett (d), triplet ( $t$ ) or triplet of triplets ( $\mathrm{tt}$ ). Melting points were determined with a Krüss KSP1N melting point apparatus and are uncorrected. IR spectra were recorded on a Perkin-Elmer Spectrum 100 FT ATR (attenuated total reflection) IR spectrophotometer. Elemental analyses were performed in the microanalytical laboratory of the University of Konstanz.

\subsection{Chemistry}

\subsubsection{Bis-[(p-methoxybenzyl)cyclopentadienyl]titanium(IV)} dichloride (2)

A solution of 6(4-methoxyphenyl)fulvene (1) $(15.0 \mathrm{~g}, 81.4 \mathrm{mmol})$ in anhydrous THF $(100 \mathrm{ml})$ was added to a solution of lithium triethylborohydride $(77.4 \mathrm{ml}, 77.4 \mathrm{mmol})$ in THF over $1 \mathrm{~h}$ and the resulting yellow solution was stirred at room temperature (RT) till turning colorless $(\sim 12 \mathrm{~h})$. The solution was cooled to $0^{\circ} \mathrm{C}$ and a solution of $\mathrm{TiCl}_{4}$ in toluene $(36.4 \mathrm{ml}, 36.4 \mathrm{mmol})$ was added. The deep red solution was stirred for $36 \mathrm{~h}$ and the precipitating red solid was filtered off and washed with cold toluene $(100 \mathrm{ml})$. The remaining red solid was taken up in a sufficient amount of $\mathrm{CH}_{2} \mathrm{Cl}_{2}$ and filtered again. The solvent was evaporated to give 2 as red micro crystals (12.0 g, $24.5 \mathrm{mmol}, 63 \%$ ). The characterization of compound 2 is in agreement with the parameters reported elsewhere [16].

\subsubsection{Bis-l(p-methoxybenzyl)cyclopentadienyl]titanium(IV) dimethyl (3)}

A solution of MeLi in $\mathrm{Et}_{2} \mathrm{O}(22.4 \mathrm{ml}, 2.3 \mathrm{M}, 51.5 \mathrm{mmol}, 1.05 \mathrm{eq}$.) was added to a suspension of $2(12.0 \mathrm{~g}, 24.5 \mathrm{mmol})$ in $\mathrm{Et}_{2} \mathrm{O}(250 \mathrm{ml})$ over $30 \mathrm{~min}$ at $-15^{\circ} \mathrm{C}$. The mixture was allowed to warm to RT and stirred for $12 \mathrm{~h} . \mathrm{CH}_{2} \mathrm{Cl}_{2}(150 \mathrm{ml})$ was added and the organic phase washed three times with cold water $(100 \mathrm{ml})$ and finally dried over $\mathrm{MgSO}_{4}$. After evaporation of the solvent and recrystallization from pentane, 3 was obtained as yellow crystalline solid $(9.7 \mathrm{~g}, 21.6 \mathrm{mmol}$ $88 \%$ ) of m.p. $107.5-108.5^{\circ} \mathrm{C} ;{ }^{1} \mathrm{H}-\mathrm{NMR}\left(600.1 \mathrm{MHz}, \mathrm{CDCl}_{3}\right.$, s: singlet, d: doublet, t: triplet, tt: triplet of triplets): $\delta=7.19$ (d, $J=8.6 \mathrm{~Hz}, 4 \mathrm{H}$, $\left.\mathrm{H}_{\mathrm{ar}}\right), 6.87\left(\mathrm{~d}, J=8.6 \mathrm{~Hz}, 4 \mathrm{H}, \mathrm{H}_{\mathrm{ar}}\right), 5.96\left(\mathrm{t}, J=2.6 \mathrm{~Hz}, 4 \mathrm{H}, \mathrm{H}_{\mathrm{Cp}}\right), 5.69(\mathrm{t}$, $\left.J=2.6 \mathrm{~Hz}, 4 \mathrm{H}, \mathrm{H}_{\mathrm{Cp}}\right), 3.80\left(\mathrm{~s}, 6 \mathrm{H}, \mathrm{OCH}_{3}\right), 3.72\left(\mathrm{~s}, 4 \mathrm{H}, \mathrm{CH}_{2}\right),-0.14(\mathrm{~s}, 6 \mathrm{H}$, $\left.\mathrm{TiCH}_{3}\right)$ ppm; ${ }^{13} \mathrm{C}-\mathrm{NMR}\left(150.9 \mathrm{MHz}, \mathrm{CDCl}_{3}\right): \delta=158.0\left(\mathrm{CH}_{3} \mathrm{OC}_{\mathrm{ar}}\right) 133.3$ $\left(\mathrm{CH}_{2} \mathrm{C}_{\mathrm{ar}}\right), 129.6\left(\mathrm{HC}_{\mathrm{ar}}\right), 128.3\left(\mathrm{CH}_{2} \mathrm{C}_{\mathrm{Cp}}\right), 114.5\left(\mathrm{HC}_{\mathrm{Cp}}\right), 113.9\left(\mathrm{HC}_{\mathrm{ar}}\right)$, $111.0\left(\mathrm{HC}_{\mathrm{Cp}_{\mathrm{p}}}\right), 55.3\left(\mathrm{OCH}_{3}\right), 44.5\left(\mathrm{TiCH}_{3}\right), 35.7\left(\mathrm{CH}_{2}\right) \mathrm{ppm}$; Elemental analysis calcd (\%) for $\mathrm{C}_{28} \mathrm{H}_{32} \mathrm{O}_{2}$ Ti: $\mathrm{C}, 75.00 ; \mathrm{H}, 7.19$; found: $\mathrm{C}, 74.56 ; \mathrm{H}$, 7.29; IR (neat) $v=3000,1650,1570,1250,820 \mathrm{~cm}^{-1}$.

\subsection{Ligand exchange}

\subsubsection{Bis-I(p-methoxybenzyl)cyclopentadienyl]titanium(IV)} oxalate (13)

To oxalic acid (8) (213 $\mathrm{mg}, 2.37 \mathrm{mmol}$ ) suspended in anhydrous THF $(40 \mathrm{ml})$ was added a solution of $3(1.06 \mathrm{~g}, 2.37 \mathrm{mmol})$ in anhydrous THF $(20 \mathrm{ml})$. The mixture was stirred for $12 \mathrm{~h}$ at RT and half of the solvent was evaporated. The evolving solid was filtered off and washed with cold THF $(40 \mathrm{ml})$. Recrystallization from toluene/ THF gave the oxalate 13 in $72 \%$ yield $(1.70 \mathrm{~mol}, 860 \mathrm{mg}$ ) and m.p. $194.5-195.5^{\circ} \mathrm{C}$.

${ }^{1} \mathrm{H}-\mathrm{NMR}\left(600.1 \mathrm{MHz}, \mathrm{CDCl}_{3}\right) \hat{\delta}=7.03\left(\mathrm{~d}, J=8.7 \mathrm{~Hz}, 4 \mathrm{H}, \mathrm{C}_{\mathrm{ar}}\right), 6.82$ $\left(\mathrm{d}, J=8.7 \mathrm{~Hz}, 4 \mathrm{H}, \mathrm{C}_{\mathrm{ar}}\right), 6.54\left(\mathrm{t}, J=2.6 \mathrm{~Hz}, 4 \mathrm{H}, \mathrm{C}_{\mathrm{Cp}}\right), 6.19(\mathrm{t}, J=2.6 \mathrm{~Hz}$ $\left.4 \mathrm{H}, \mathrm{C}_{\mathrm{Cp}}\right), 3.77\left(\mathrm{~s}, 6 \mathrm{H}, \mathrm{OCH}_{3}\right), 3.68\left(\mathrm{~s}, 4 \mathrm{H}, \mathrm{CH}_{2}\right) \mathrm{ppm} ;{ }^{13} \mathrm{C}-\mathrm{NMR}$ $\left(150.9 \mathrm{MHz}, \mathrm{CDCl}_{3}\right) \delta=162.9(\mathrm{OC}=\mathrm{OTi}), 158.6\left(\mathrm{CH}_{3} \mathrm{OC} \mathrm{ar}\right), 143.6$ $\left(\mathrm{CH}_{2} \mathrm{C}_{\mathrm{Cp}}\right), 130.1\left(\mathrm{HC}_{\mathrm{Ar}}\right), 129.5\left(\mathrm{CH}_{2} \mathrm{C}_{\mathrm{ar}}\right), 121.6\left(\mathrm{HC}_{\mathrm{Cp}}\right), 119.8\left(\mathrm{HC}_{\mathrm{Cp}}\right)$, 114.1 $\left(\mathrm{HC}_{\mathrm{ar}}\right), 55.3\left(\mathrm{OCH}_{3}\right), 35.1\left(\mathrm{CH}_{2}\right) \mathrm{ppm}$; Elemental analysis calcd (\%) for $\mathrm{C}_{28} \mathrm{H}_{26} \mathrm{O}_{6} \mathrm{Ti}: \mathrm{C}, 66.41 ; \mathrm{H}, 5.18$; found: $\mathrm{C}, 66.13 ; \mathrm{H}, 5.06$; IR (neat) $v=3155,1720,1300,790 \mathrm{~cm}^{-1}$.

\subsubsection{Bis-I(p-methoxybenzyl)cyclopentadienyl]titanium(IV) malonate (14)}

To malonic acid (9) (347 $\mathrm{mg}, 3.34 \mathrm{mmol}$ ) in anhydrous THF $(50 \mathrm{ml})$ was added a solution of $3(1.5 \mathrm{~g}, 3.34 \mathrm{mmol})$ in anhydrous THF $(20 \mathrm{ml})$. The mixture was stirred for $12 \mathrm{~h}$ at RT and the solvent was evaporated. The remaining solid was recrystallized from $\mathrm{CH}_{2} \mathrm{Cl}_{2} /$ toluene to give the malonate $\mathbf{1 4}$ as red powder $(615 \mathrm{mg}, 1.2 \mathrm{mmol}$, $35 \%$ ) of m.p.: $69{ }^{\circ} \mathrm{C}$. Although the analysis data for " $\mathrm{C}$ " are somewhat unsatisfactory, the spectroscopic analysis data are reasonably support the formula.

${ }^{1} \mathrm{H}-\mathrm{NMR}\left(600.1 \mathrm{MHz}, \mathrm{CDCl}_{3}\right): \delta=7.07\left(\mathrm{~d}, J=8.4 \mathrm{~Hz}, 4 \mathrm{H}, \mathrm{C}_{\mathrm{az}}\right), 6.83$ $\left(\mathrm{d}, J=8.4 \mathrm{~Hz}, 4 \mathrm{H}, \mathrm{C}_{\mathrm{ar}}\right), 6.43\left(\mathrm{~d}, J=4.6 \mathrm{~Hz}, 4 \mathrm{H}, \mathrm{C}_{\mathrm{Cp}}\right), 6.19\left(\mathrm{~s}, 4 \mathrm{H}, \mathrm{C}_{\mathrm{Cp}}\right)$, $3.78\left(\mathrm{~s}, 6 \mathrm{H}, \mathrm{OCH}_{3}\right), 3.37\left(\mathrm{~s}, 4 \mathrm{H}, \mathrm{C}_{\mathrm{ar}} \mathrm{CH}_{2}\right), 3.28\left(\mathrm{~s}, \mathrm{C}=\mathrm{OCH}_{2} \mathrm{C}=0\right) \mathrm{ppm}$; ${ }^{13} \mathrm{C}$-NMR (150.9 MHz, $\left.\mathrm{CDCl}_{3}\right): \delta=171.9(\mathrm{OC}=$ OTi $), 158.5\left(\mathrm{CH}_{3} \mathrm{OC} \mathrm{Cr}\right)$, $143.1\left(\mathrm{CH}_{2} \mathrm{C}_{\mathrm{Cp}}\right), 130.1\left(\mathrm{CH}_{2} \mathrm{C}_{\mathrm{ar}}\right), 129.9\left(\mathrm{HC}_{\mathrm{Ar}}\right), 119.2\left(\mathrm{HC}_{\mathrm{Cp}}\right), 115.0$ $\left(\mathrm{HC}_{\mathrm{ar}}\right), 55.2\left(\mathrm{OCH}_{3}\right), 37.3\left(\mathrm{CH}_{2} \mathrm{C}_{\mathrm{ar}}\right), 34.9\left(\mathrm{O}(\mathrm{O}=\mathrm{C})-\mathrm{CH}_{2}-(\mathrm{C}=0) \mathrm{O}\right)$ ppm; Elemental analysis calcd (\%) for $\mathrm{C}_{29} \mathrm{H}_{28} \mathrm{O}_{6} \mathrm{Ti}: \mathrm{C}, \overline{66.93} ; \mathrm{H}, 5.42$; found: $\mathrm{C}, 66.03 ; \mathrm{H}, 5.18$; IR (neat) $v=2990,1640,1520,1240$, $815 \mathrm{~cm}^{-1}$.

\subsubsection{Bis-I(p-methoxybenzyl)cyclopentadienyl]titanium(IV)} cyclopropane-1,1-dicarboxylate (15)

To cyclopropane-1,1-dicarboxylic acid (10) (247 mg, $1.9 \mathrm{mmol}$ ) was added a solution of $3(848 \mathrm{mg}, 1.9 \mathrm{mmol})$ in anhydrous THF $(25 \mathrm{ml})$. The mixture was stirred for $4 \mathrm{~h}$ at $\mathrm{RT}$ and the solvent was evaporated at ambient temperature. The remaining solid was recrystallized from toluene/ $/ \mathrm{Et}_{2} \mathrm{O}$ to yield the cyclopropane-1,1dicarboxylate 15 as red crystals ( $425 \mathrm{mg}, 0.78 \mathrm{mmol}, 41 \%$ ) of m.p. $165.0-168{ }^{\circ} \mathrm{C} ;{ }^{1} \mathrm{H}-\mathrm{NMR}\left(600.1 \mathrm{MHz}, \mathrm{CDCl}_{3}\right) \delta=7.07(\mathrm{~d}, J=8.6 \mathrm{~Hz}, 4 \mathrm{H}$, $\left.\mathrm{C}_{\mathrm{arl}}\right), 6.82\left(\mathrm{~d}, J=8.6 \mathrm{~Hz}, 4 \mathrm{H}, \mathrm{C}_{\mathrm{at}}\right), 6.47\left(\mathrm{t}, J=2.6 \mathrm{~Hz}, 4 \mathrm{H}, \mathrm{C}_{\mathrm{Cp}}\right), 6.18(\mathrm{t}$, $\left.J=2.6 \mathrm{~Hz}, 4 \mathrm{H}, \mathrm{C}_{\mathrm{cp}}\right), 3.78\left(\mathrm{~s}, 6 \mathrm{H}, \mathrm{OCH}_{3}\right), 3.72\left(\mathrm{~s}, 4 \mathrm{H}, \mathrm{C}_{\mathrm{ar}} \mathrm{CH}_{2}\right), 1.76(\mathrm{~s}, 4 \mathrm{H}$, $\left.\mathrm{CH}_{2} \mathrm{CH}_{2}\right) \mathrm{ppm} ;{ }^{3} \mathrm{C}$-NMR $\left(150.9 \mathrm{MHz}, \mathrm{CDCl}_{3}\right) \delta=174.7$ (OC=OTi), $158.4\left(\mathrm{CH}_{3} \mathrm{OC}_{\mathrm{ar}}\right), 142.4\left(\mathrm{CH}_{2} \mathrm{C}_{\mathrm{Cp}_{\mathrm{p}}}\right), 130.3\left(\mathrm{CH}_{2} \mathrm{C}_{\mathrm{ar}}\right), 130.1\left(\mathrm{HC}_{\mathrm{Ar}}\right), 119.4$ $\left(\mathrm{HC}_{\mathrm{cp}}\right), 118.3\left(\mathrm{HC}_{\mathrm{cp}}\right), 114.0\left(\mathrm{HC}_{\mathrm{ar}}\right), 55.3\left(\mathrm{OCH}_{3}\right), 34.9\left(\mathrm{CH}_{2} \mathrm{C}_{\mathrm{ar}}\right), 23.8$ $\left(\mathrm{C}_{\mathrm{quart}}\right), 23.6\left(\mathrm{CH}_{2} \mathrm{CH}_{2}\right)$ ppm; Elemental analysis calcd $(\%)$ for $\mathrm{C}_{31} \mathrm{H}_{30} \mathrm{O}_{6} \mathrm{Ti}: \mathrm{C}, 68.14 ; \mathrm{H}, 5.53$; found: $\mathrm{C}, 68.20 ; \mathrm{H}, 5.36$; IR (neat) $\eta=3090,1632,1508,1348,1228,831 \mathrm{~cm}^{-1}$.

\subsubsection{Bis-I(p-methoxybenzyl)cyclopentadienyl]titanium(IV)} cyclobutane-1,1-dicarboxylate (16)

To cyclobutane-1,1-dicarboxylic acid (11) (107 mg, $0.74 \mathrm{mmol}$ ) suspended in anhydrous THF ( $5 \mathrm{ml}$ ) was added a solution of 3 (333 $\mathrm{mg}, 0.74 \mathrm{mmol}$ ) in anhydrous THF $(5 \mathrm{ml})$. The mixture was stirred for $12 \mathrm{~h}$ at RT and the solvent evaporated. The remaining orange solid was recrystallized from $\mathrm{CH}_{2} \mathrm{Cl}_{2}$ /pentane to give cyclobutane-1,1-dicarboxylate $16(187 \mathrm{mg}, 0.33 \mathrm{mmol}, 45 \%)$ as yellowish solid of m.p. $85.5-86.5^{\circ} \mathrm{C} ;{ }^{1} \mathrm{H}-\mathrm{NMR}\left(600.1 \mathrm{MHz}, \mathrm{CDCl}_{3}\right): \delta=7.06$ (d, $\left.J=8.6 \mathrm{~Hz}, 4 \mathrm{H}, \mathrm{Car}_{\mathrm{ar}}\right), 6.82\left(\mathrm{~d}, J=8.6 \mathrm{~Hz}, 4 \mathrm{H}, \mathrm{C}_{\mathrm{ar}}\right), 6.38(\mathrm{t}, J=2.6 \mathrm{~Hz}, 4 \mathrm{H}$, $\left.\mathrm{C}_{\mathrm{Cp}}\right), 6.12\left(\mathrm{t}, J=2.6 \mathrm{~Hz}, 4 \mathrm{H}, \mathrm{C}_{\mathrm{Cp}}\right), 3.77\left(\mathrm{~s}, 6 \mathrm{H}, \mathrm{OCH}_{3}\right), 3.66(\mathrm{~s}, 4 \mathrm{H}$, $\left.\mathrm{C}_{\mathrm{ar}} \mathrm{CH}_{2}\right), 2.69\left(\mathrm{t}, J=8.0 \mathrm{~Hz}, 4 \mathrm{H}, \mathrm{CH}_{2} \mathrm{CH}_{2} \mathrm{CH}_{2}\right), 2.23(\mathrm{tt}, J=8.0 \mathrm{~Hz}, 2 \mathrm{H}$, $\mathrm{CH}_{2} \mathrm{CH}_{2} \mathrm{CH}_{2}$ ) ppm; ${ }^{13} \mathrm{C}-\mathrm{NMR}\left(150.9 \mathrm{MHz}, \mathrm{CDCl}_{3}\right): \delta=178.7$ $(\mathrm{OC}=\overline{\mathrm{OTi}}), 159.4\left(\mathrm{CH}_{3} \mathrm{OC}\right.$ ar $), 143.3\left(\mathrm{CH}_{2} \mathrm{C}_{\mathrm{Cp}}\right), 131.1\left(\mathrm{CH}_{2} \mathrm{C}_{\mathrm{ar}}\right), 130.9$ $\left(\mathrm{HC}_{\mathrm{Ar}}\right), 119.8\left(\mathrm{HC}_{\mathrm{Cp}}\right), 11 \overline{5} .0\left(\mathrm{HC}_{\mathrm{ar}}\right), 56.3\left(\mathrm{OCH}_{3}\right), 47.1\left(\mathrm{CH}_{2} \mathrm{C}_{\mathrm{ar}}\right), 35.9$ 
$\left(\mathrm{C}_{\text {quart }}\right), 31.7\left(\mathrm{CH}_{2} \mathrm{CH}_{2} \mathrm{CH}_{2}\right), 17.4\left(\mathrm{CH}_{2} \mathrm{CH}_{2} \mathrm{CH}_{2}\right)$ ppm; Elemental analysis calcd (\%) for $\mathrm{C}_{32} \mathrm{H}_{32} \mathrm{O}_{6} \mathrm{Ti}: \mathrm{C}, 68.58 ; \mathrm{H}, 5.75$; found: $\mathrm{C}, 68.64$; $\mathrm{H}, 5.72$; IR (neat) $v=2900,1625,1500,1250,810 \mathrm{~cm}^{-1}$.

2.3.5. Bis-l(p-methoxybenzyl)cyclopentadienyl]titanium(IV) pyridine2,6-dicarboxylate (17)

To pyridine-2,6-dicarbonic acid (12) (187 $\mathrm{mg}, 1.12 \mathrm{mmol})$ suspended in anhydrous THF $(10 \mathrm{ml})$ was added a solution of $3(500 \mathrm{mg}$. $1.12 \mathrm{mmol}$ ) in anhydrous THF (5 ml). The mixture was stirred for $12 \mathrm{~h}$ at $\mathrm{RT}$ and the solvent was evaporated. The remaining yellow solid was recrystallized from $\mathrm{CH}_{2} \mathrm{Cl}_{2}$ /toluene to give the pyridine-2,6-dicarboxylate 17 as yellow crystals ( $276 \mathrm{mg}, 0.47 \mathrm{mmol}, 42 \%$ ) of m.p. 147.0 $147.5^{\circ} \mathrm{C} ;{ }^{1} \mathrm{H}-\mathrm{NMR}\left(600.1 \mathrm{MHz}, \mathrm{CDCl}_{3}\right) \delta=8.34-8.30\left(\mathrm{~m}, 3 \mathrm{H}, \mathrm{C}_{\mathrm{pyr}} \mathrm{H}\right)$ $6.89\left(\mathrm{~d}, J=8.7 \mathrm{~Hz}, 4 \mathrm{H}, \mathrm{C}_{\mathrm{ar}}\right), 6.73\left(\mathrm{~d}, J=8.7 \mathrm{~Hz}, 4 \mathrm{H}, \mathrm{C}_{\mathrm{ar}}\right), 6.22(\mathrm{t}$, $\left.J=2.6 \mathrm{~Hz}, 4 \mathrm{H}, \mathrm{C}_{\mathrm{Cp}}\right), 5.85\left(\mathrm{t}, J=2.6 \mathrm{~Hz}, 4 \mathrm{H}, \mathrm{C}_{\mathrm{Cp}}\right), 3.73\left(\mathrm{~s}, 6 \mathrm{H}, \mathrm{OCH}_{3}\right)$, $3.32\left(\mathrm{~s}, 4 \mathrm{H}, \mathrm{C}_{\mathrm{ar}} \mathrm{CH}_{2}\right) \mathrm{ppm} ;{ }^{13} \mathrm{C}-\mathrm{NMR}\left(150.9 \mathrm{MHz}, \mathrm{CDCl}_{3}\right) \delta=165.6$ $(\mathrm{OC}=\mathrm{O}), 158.2\left(\mathrm{CH}_{3} \mathrm{OC}\right.$ ar $), 150.5\left(\mathrm{C}_{\mathrm{pyr}} \mathrm{N}\right), 143.5\left(\mathrm{C}_{\mathrm{pyr}} \mathrm{H}\right), 136.8$ $\left(\mathrm{C}_{\mathrm{Cp}} \mathrm{CH}_{2}\right), 130.7\left(\mathrm{C}_{\mathrm{ar}} \mathrm{CH}_{2}\right), 129.5\left(\mathrm{C}_{\mathrm{ar}} \mathrm{H}\right), 126.3\left(\mathrm{C}_{\mathrm{pyr}} \mathrm{H}\right), 120.2\left(\mathrm{C}_{\mathrm{Cp}} \mathrm{H}\right)$ $114.7\left(\mathrm{C}_{\mathrm{cp}} \mathrm{H}\right), 114.0\left(\mathrm{C}_{\mathrm{ar}} \mathrm{H}\right), 55.2\left(\mathrm{CH}_{3} \mathrm{OC}_{\mathrm{ar}}\right), 34.7\left(\mathrm{CH}_{2}\right) \mathrm{ppm}$; Elemental analysis calcd (\%) for $\mathrm{C}_{33} \mathrm{H}_{29} \mathrm{NO}_{6} \mathrm{Ti}: \mathrm{C}, 67.93 ; \mathrm{H}, 5.01 ; \mathrm{N}$, 2.40 ; found: $\mathrm{C}, 67.94 ; \mathrm{H}, 5.19 ; \mathrm{N}, 2.17$; IR (neat) $v=2810,1650,1250$, $700 \mathrm{~cm}^{-1}$

\subsection{Cytotoxicity assays}

\subsubsection{Cell lines and culture conditions}

Cells of human HeLa S3 cervix carcinoma were obtained from European Collection of Cell Cultures (ECACC) and cultivated at $37^{\circ} \mathrm{C}$ in a humidified $5 \% \mathrm{CO}_{2}$ atmosphere using Dulbecco's DMEM-media (Invitrogen) containing $10 \%$ foetal calf serum, $1 \%$ penicillin and $1 \%$ streptomycin. Cells were split every three days. Cells were routinely tested for mycoplasma infections using a mycoplasma detection kit (Roche Applied Science) prior usage.

\subsubsection{AlamarBlue assay [33]}

AlamarBlue (BioSource Europe), the dark blue colored sodium salt of resazurin (7-Hydroxy-3H-phenoxazin-3-one-10-oxide) was used to measure growth and viability of cells which are capable of reducing it to the fluorescent, pink colored resorufin (7-Hydroxy- $3 \mathrm{H}$-phenoxazin-3-one). Cells were seeded in 96-well plates ( 4000 HeLa $\$ 3$ cells/ well or 8000 Hep G2 cells/well) and allowed to attach for $24 \mathrm{~h}$. Complexes to be tested were dissolved in a suitable amount of DMSO. Different concentrations were prepared by serial dilution with medium to give final concentrations with a maximum DMSO content of $1 \%$. The cells were then incubated for $48 \mathrm{~h}$ with $100 \mu \mathrm{l}$ each of above dilution series. AlamarBlue $(10 \mu \mathrm{l})$ was added and the cells were incubated for another hour. After excitation at $530 \mathrm{~nm}$, fluorescence at $590 \mathrm{~nm}$ was measured using a FL600 Fluorescence Microplate Reader (Bio-TEK). Cell viability is expressed in percent with respect to a control containing only pure medium and $1 \%$ DMSO incubated under identical conditions. All experiments were repeated for a minimum of three times with each experiment done in four replicates. The resulting curves were fitted using Sigma plot 10.0 [34].

\section{Results and discussion}

\subsection{Synthesis}

Herein, we describe a short and efficient synthesis of a small library of bidentate derivatives of titanocene $Y$ starting from a common precursor. This new precursor, dimethyl titanocene $Y \mathbf{3}$, is accessible in a yield of $88 \%$ starting from the already known titanocene $Y 2$. Its known synthesis involves time consuming drying of Superhydride-solution which is not well suited for preparation of larger amounts of $\mathbf{2}$. Therefore, we developed a modified one-pot hydrido-lithiation-metallation sequence starting from fulvene 1 . This allowed us the preparation of multigram quantities of titanocene dichloride $\mathbf{2}$ in a time efficient manner and good overall yield. Analogous to the synthesis of dimethyl titanocene [35], 3 is accessible by the simple methylation of 2 with equimolar amounts of an ethereal solution of methyllithium at $-15^{\circ} \mathrm{C}$ (Scheme 1). Addition of cold water for the following extraction with dichloromethane did not result in a noteworthy amount of hydrolyzed product. 3 was isolated in $88 \%$ yield and analytical pure after a standard aqueous work up. The ${ }^{1} \mathrm{H}$-NMR-spectrum showed the characteristic shift of the metal bound methyl group whose protons resonate as sharp singlet at $-0.14 \mathrm{ppm}$. The combustion analysis of the obtained yellow, microcrystalline product showed no organic or inorganic contaminations. Even exposed to air, dried dimethyl titanocene $Y 3$ was stable for several months at room temperature, demonstrating its pronounced robustness.

In a first attempt to derivatize 3 , the reaction with different bidentate alcohols and thiols was investigated (Scheme 2). A nucleophilic attack of the alcohol at the metal centre should lead to the formation of a cyclic titanium alkoxide with an O-Ti-O motive and concomitant liberation of methane. A solution of 3 in THF was therefore treated with half molar amounts of ethane-1,2-diol (4), propane-1,3-diol (5), and pinacol (7) in THF at RT respectively. Since liberation of methane was not detectable, the reaction was heated under reflux for $12 \mathrm{~h}$. Interestingly, NMR spectra of the crude revealed the exclusive presence of starting material. Considering the known oxophilicity of titanium, the inertness of 3 towards 0 -nucleophiles is quite surprising. Reaction with ethane-1,2-dithiol (6) proved to be unsuccessful as well, again only starting complex 3 was isolated after removal of the solvent.

As a prerequisite for the nucleophilic displacement at the metal centre, the titanium bound methide has to be protonated, either by

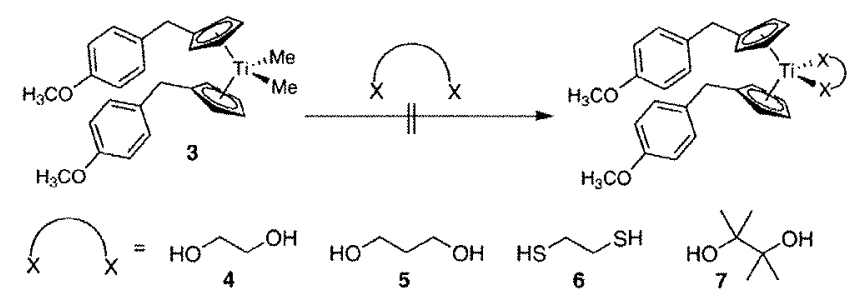

Scheme 2. Attempted derivatization of dimethyl titanocene $Y(3)$ using different diols and ethandithiole. In all cases, no reaction was observed even after $12 \mathrm{~h}$ in refluxing THF, underlining the unexpected stability of 3 .

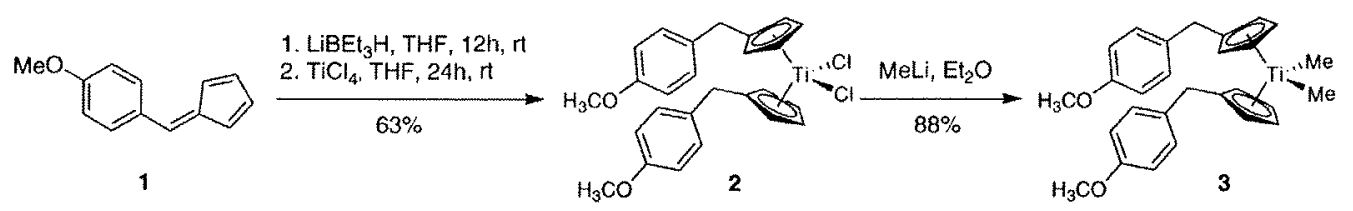

Scheme 1. One-pot synthesis of titanocene $Y(2)$ and its methylation to dimethyl titanocene $Y(3)$. 


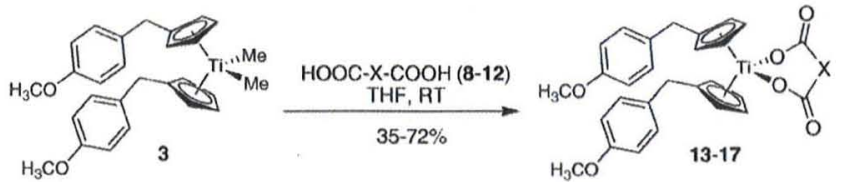

Scheme 3. Derivatization of dimethyl titanocene $Y(3)$ using different dicarboxylic acids. The resulting complexes could be isolated in moderate to good yield.

the incoming nucleophile or by a different proton source. The actual substitution process then would follow a dissociative interchange ( $\mathrm{S}_{\mathrm{N}} 1$-type) pathway. With a $\mathrm{pk}_{\mathrm{A}}$ of 14.22 for the dissociation of the first proton, ethane-1,2-diol is only rather weak acidic [36]. Presumably this low acidity and, in the case of the pinacol the sterical demand, efficiently suppresses ligand exchange under these conditions.

As a logical consequence from above results, the reaction with more acidic bidentates was considered. Dicarboxylic acids like oxalic (8), malonic (9) or cyclopropane-1,1-dicarboxylic (10), cyclobutane-1,1dicarboxylic (11) or pyridyl-2,6-dicarboxylic acid (12) seemed suitable with respect to chelate formation ability and acidity (Scheme 3 ). The pKa values for the exchange of the first proton are in the range of 1.23 and 2.83 for oxalic and malonic acid, with the others lying in-between [37]. Experiments were run in THF under exclusion of humidity and oxygen using schlenk technique. Preparation of the titanocene $\mathrm{Y}$ dicarboxylates 13-17 was achieved by slowly adding a solution of dimethyl titanocene $\mathrm{Y}(\mathbf{3})$ in THF to a suspension of the respective dicarboxylic acid in THF. Stirring was continued till the evolution of methane ceased. Subsequent removal of the solvent and recrystallization of the crude from the solvents given in the experimental part gave the analytical pure titanium dicarboxylates 13-17 (Table 1). Whereas the synthesis of oxali titanocene $Y 13$ proceeded in good yield, the others were isolated in diminished yields due to solubility problems in the course of recrystallization. Even so the cyclopropane-1,1-dicarboxylate $\mathbf{1 5}$ and the pyridine-2,6-dicarboxylate $\mathbf{1 7}$ were isolated as crystalline solids, attempts to grow crystals suitable for X-ray structure determination were meet with failure.

\subsection{Biological evaluation}

The in vitro cytotoxicity of bidentate titanocene $Y$ derivatives $\mathbf{1 3}$ 17 was studied in the human cervix carcinoma cell line HeLa S3. Cell viability was quantified using the well established AlamarBlue assay, which is known to be highly reproducible and more sensitive than the MTT (3-(4,5-dimethylthiazol-2-yl)-2,5-diphenyltetrazolium bromide) assay [37]. For the purpose of standardization and comparison cisplatin was used as internal reference in all assays. It showed an $\mathrm{IC}_{50}$ value of $1.2 \pm 0.4 \mu \mathrm{M}$ in HeLa S3 and $3.0 \pm 1.3$ in Hep G2 cells.

In addition to the bidentates 13-17, the unexpected stability of titanocene Y $\mathbf{3}$ encouraged us, besides utilizing it as common precursor for above titanium bidentate complexes, to test its inherent cytotoxicity. Finally, titanocene Y (2) being already known as highly cytotoxic in LLC-PK cells from results of the Tacke group [16], was tested as well.

As shown in Table 2, dimethyl titanocene $\mathrm{Y}(\mathbf{3})$ with an $\mathrm{IC}_{50}$ value of $14.4 \mu \mathrm{M}$ is more than four times as active as titanocene $\mathrm{Y}$ itself $(63.1 \mu \mathrm{M})$. Taking into account the much higher hydrolytic stability,

Table 2

$\mathrm{IC}_{50}$ values $[\mu \mathrm{M}]$ of the synthesized complexes measured by the AlamarBlue assay in HeLa S3 cells.

\begin{tabular}{llllllll}
\hline Complex & 2 & 3 & 13 & 14 & 15 & 16 & 17 \\
\hline Hela S3 & $63.1 \pm$ & $14.4 \pm$ & $80.4 \pm$ & n. t. $^{\text {a }}$ & $126 \pm$ & $311 \pm$ & $19.3 \pm$ \\
& 1.8 & 1.3 & 46.8 & & 44.5 & 65.2 & 2.8 \\
\hline
\end{tabular}

${ }^{a}$ Non-toxic, $\mathrm{IC}_{50}$-value $>350 \mu \mathrm{M}$.

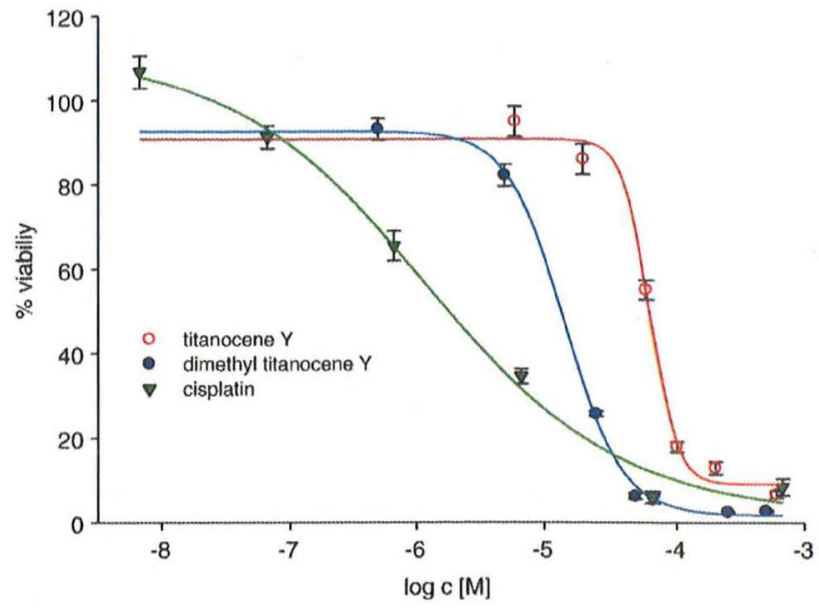

Fig. 1. Dose-response curves of Hela S3 cell viability after $48 \mathrm{~h}$ of incubation measured by AlamarBlue assay. The biological activities of dimethyl titanocene $Y$, titanocene $Y$ and cisplatin are compared.

dimethyl titanocene $Y$ might not only have a higher cytotoxicity, but also might display an improved pharmacological profile and could be a valuable tool as the fast formation of hydrolysis products hampers mechanistic biochemical research. Fig. 1 shows the results for dimethyl titanocene $Y(3)$ compared to titanocene $Y(2)$ and cisplatin in Hela S3 cells.

Surprisingly, when testing the cytotoxicity of the synthesized bidentate complexes, we could not reproduce the outstanding cytotoxicity published for oxali-titanocene Y (13) [31]. In fact, 13 was with an $\mathrm{IC}_{50}$ value of $80.4 \mu \mathrm{M}$ even slightly less active in HeLa S3 cells than titanocene $\mathrm{Y}$ itself $(63.1 \mu \mathrm{M}$, Fig. 2, Table 2$)$.

A possibility for the low cytotoxicity might be attributed to the fact that our synthesis of oxali-titanocene $Y$ does not utilize silver salts as does the original procedure. Traces of toxic silver species which stem from the initially used silver oxalate are difficult to separate from the product. This effect might add to the overall cytotoxicity of the oxalicomplex, thereby distorting the outcome of the biological assay. Another possible reason for this quite unexpected finding could be the different cell lines used. Possibly oxali-titanocene Y (13) acts much more selective than titanocene $Y(2)$. While having the same reduced toxicity in the human cervix carcinoma cell line HeLa S3 as $\mathbf{2 , 1 3}$ could be much more active in the porcine kidney cell line LLC-PK.

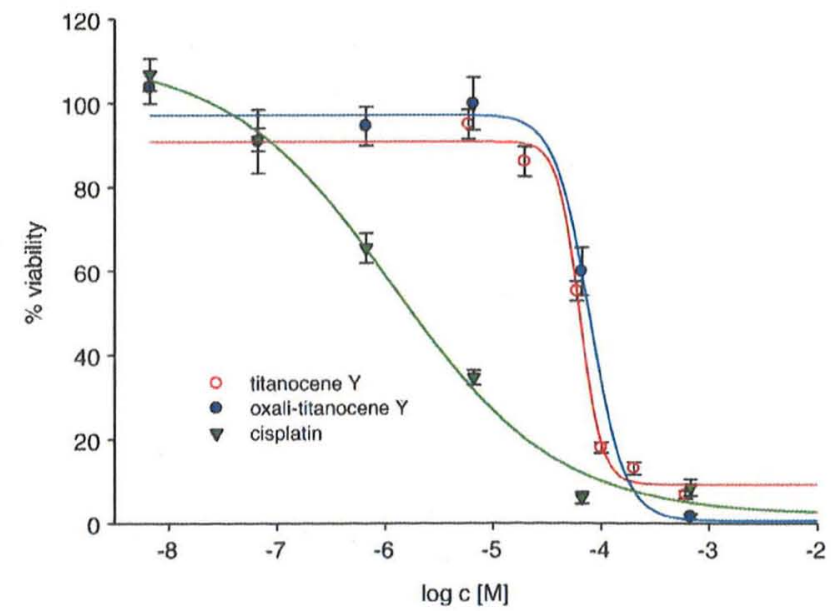

Fig. 2. Dose-response curves of Hela S3 cell viability after $48 \mathrm{~h}$ of incubation measured by AlamarBlue assay. The biological activities of titanocene $Y(2)$, oxali-titanocene $Y$ (13) and cisplatin are compared. 


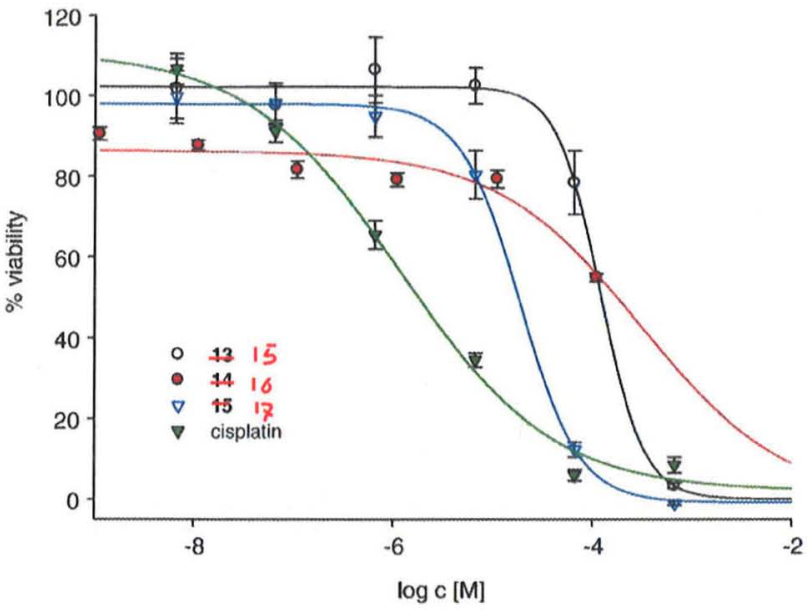

Fig. 3. Dose-response curves of Hela S3 cell viability after $48 \mathrm{~h}$ of incubation measured by AlamarBlue assay. Shown are the biological activities of the dipicolinate derivative 17 of titanocene $Y$ and the respective 1,1-dicarboxylates 15 and 16.

Screening the cytotoxicity of the other derivatives of $\mathbf{2}$, we found, that bidentates derived from malonic acid (9) and its derivatives 1011 resulted in complexes with generally reduced cytotoxicity compared to the starting dimethyl titanocene $Y$. Whereas the toxicity of the malonic acid complex $\mathbf{1 4}$ is best described as being nontoxic $\left(\mathrm{IC}_{50}>350 \mu \mathrm{M}\right)$, the substituted malono complexes show a step wise decrease of cytotoxicity with increased ring size. With an $\mathrm{IC}_{50}$ value of $125.5 \mu \mathrm{M}$ the smaller cyclopropane-1,1-dicarboxylic acid derivative 10 was only two fold less active than titanocene $Y$, whereas the cyclobutane-derivative $\mathbf{1 1}$ showed, with an $\mathrm{IC}_{50}$ value of $310.6 \mu \mathrm{M}$ a 5 fold decreased activity compared to 2 .

Surprisingly, the pyridine-2,6 dicarboxylate complex 17 which has an even higher steric demand showed a drastic improved $\mathrm{IC}_{50}$ value of $19.3 \mu \mathrm{M}$. Complex 17 differs from the malonic acid derivatives by an additional coordination site. Pyridine-2,6-dicarboxylic acid (12) itself is not cytotoxic in concentrations of up to $500 \mu \mathrm{M}$ and is known to act as a tridentate to dicyclopentadienyltitanium(IV) complexes. It coordinates via its two carboxylic groups and the pyridine nitrogen, making the resulting complexes enormous resistant against hydrolysis [38]. It seems that an improved hydrolytic stability enhances complex cytotoxicity whereas the size of the bidentate ligand shows no measurable influence (Fig. 3). Titanocene $Y$ is known to have an optimized geometry, with its para-substitution pattern having a favorable arrangement for coordination on the backbone of DNA [39]. Hence, the notable difference in toxicity between the assayed complexes is based on the difference of their bidentate ligands. We recently demonstrated the influence of the non-cp ligands by an exchange of chloride against fluoride in titanocene $Y$ derivatives, resulting in an up to 5 fold enhanced efficacy against Hela S3 cells [40]. Since those ligands are themselves not toxic, we argue that improving the hydrolytic robustness is advantageous in terms of cytotoxicity because otherwise complexes might get deactivated to fast.

\section{Conclusion}

We could show an efficient synthetic approach towards the hitherto unknown dimethyl titanocene Y (3) in 10 gram quantities. The viability of $\mathbf{3}$ as a valuable precursor for further functionalized cytotoxic titanocene derivatives was demonstrated by the synthesis of a small library of titanocene $Y$ derivatives. The reaction proceeded via a metal-free ligand exchange reaction with different dicarboxylic acids. Biological assays in HeLa S3 cells revealed that, oxali-titanocene Y (13) a complex so far believed to be highly cytotoxic showed no improvement compared to titanocene $\mathrm{Y}$ itself. According to our biological assays complex 17 with pyridine-2,6 dicarboxylic acid is a much more promising candidate. In Hela S3 it shows a three times higher toxicity than titanocene $Y$. Its pronounced stability against hydrolysis makes it an ideal candidate for more advanced biological studies where higher stability in aqueous media is required. Moreover, this complex offers the possibility of derivatization of the pyridine-2,6 dicarboxylate ligand in order to introduce functionalities improving solubility. Our aim is to improve solubility, hydrolytic stability and cytotoxicity. Structure activity relations will be targeted by the defined alterations in sterical demand as well as electronic properties.

\section{Acknowledgement}

The authors are grateful to the Konstanz Research School Chemical Biology (KoRS-CB) and COST D39 for financial and scientific support. T.A.l. thanks the KoRS-CB for a personal scholarship. The authors would also like to thank Dipl.-Chem. Malin Bein for help with the biological assays.

\section{References}

(1) E. Wong, C.M. Giandomenico, Chem. Rev. 99 (1999) 2451-2466.

[2] M.A. Jakupec, M. Galanski, B.K. Keppler, Rev. Physiol. Biochem. Pharmacol. 146 (2003) 1-54.

3] M. Galanski, M.A. Jakupec, B.K. Keppler, Curr. Med. Chem. 12 (2005) 2075-2094.

[4] P.C.A. Bruijnincx, P.J. Sadler, Curr. Opin. Chem. Biol. 12 (2008) 197-206.

[5] M.A. Jakupec, M. Galanski, V.B. Arion, C.G. Hartinger, B.K. Keppler, Dalton Trans. (2008) $183-194$.

[6] R. Ott, Gust, Arch. Pharm. Chem. Life Sci. 340 (2007) 117-126.

[7] N. Katsaros, A. Anagnostopoulou, Crit. Rev. Oncol. Hematol. 42 (2002) 297-308.

(8) A.M. Evang. Anagit Rev. Oncol Hemt 42 (2002) 249-265.

[8] A.M. Evangelou, Crit. Rev. Oncol. Hematol. 42 (2002)

[10] Kostova, Anticancer Agents Med. Chem. 6 (2006) 19-32

[11] F. Caruso, M. Rossi, J. Tanski, R. Sartori, R. Sariego, S. Moya, S. Diez, E. Navarrete, A. Cingolani, F. Marchetti, C. Pettinari, J. Med. Chem. 43 (2000) 3665-3670.

[12] T. Schilling, K.B. Keppler, M.E. Heim, G. Niebch, H. Dietzfelbinger, J. Rastetter, A.R. Hanauske, Invest. New Drugs 13 (1996) 327-332.

[13] H. Bischoff, M.R. Berger, B.K. Keppler, D. Schmähl, J. Cancer Res. Clin. Oncol. 113 (1987) 446-450.

[14] H. Köpf, P. Köpf-Maier, Angew. Chem. 91 (1979) 509; Angew. Chem. Int. Ed. Engl. 18 (1979) 477-478

[15] P. Köpf-Maier, F. Preiss, T. Marx, T. Klapötke, H. Köpf, Anticancer Res. 6 (1986) 33-37

[16] N.J. Sweeney, O. Mendoza, H. Müller-Bunz, C. Pampillón, F.-J.K. Rehmann, K. Strohfeldt, M. Tacke, J. Organomet. Chem. 690 (2005) 4537-4544.

[17] P.M. Abeysinghe, M.M. Harding, Dalton Trans. (2007) 3474-3482

[18] K. Strohfeldt, M. Tacke, Chem. Soc. Rev. 37 (2008) 1174-1187.

[19] P. Köpf-Maier, Eur. J. Clin. Pharmacol. 47 (1994) 1-16.

[20] C.V. Christodoulou, A.G. Eliopoulos, L.S. Young, L. Hodgkins, D.R. Ferry, D.J. Kerr, Br. J. Cancer 77 (1998) 2088-2097.

[21] M. Guo, Z. Guo, P.J. Sadler, J. Biol. Inorg. Chem. 6 (2001) 698-707.

[22] G. Mokdsi, M.M. Harding, J. Organomet. Chem. 565 (1998) 29-35.

[23] H. Sun, H. Li, R.A. Weir, P.J. Sadler, Angew. Chem. 110 (1998) 1622-1625; Angew. Chem. Int. Ed. 37 (1998) 1577-1579.

[24] M. Guo, H. Sun, H.J. McArdle, L. Gambling, P.J. Sadler, Biochemistry 39 (2000) 10023-10033.

[25] L.M. Gau, R. Hernandez, J. Matta, E. Melendez, J. Biol. Inorg. Chem. 12 (2007) 959-967.

26] A.D. Tinoco, A.M. Valentine, J. Am. Chem. Soc. 127 (2005) 11218-11219.

[27] D. Tinoco, C.D. Incarvito, A.M. Valentine, J. Am. Chem. Soc. 129 (2007) 3444-3454.

[28] D. Tinoco, E.V. Eames, A.M. Valentine, J. Am. Chem. Soc. 130 (2008) 2262-2270.

[29] J.H. Toney, T.J. Marks, J. Am. Chem. Soc. 107 (1985) 947-953.

[30] H. Köpf, S. Grabowski, R. Voigtländer, J. Organomet. Chem. 216 (1981) 185-190.

[31] J. Claffey, M. Hogan, H. Müller-Bunz, C. Pampillon, M. Tacke, ChemMedChem 3 (2008) 729-731.

[32] W.L.F. Armarego, C.L.L. Chai, Purification of Laboratory Chemicals, 5th EditionElsevier Science, 2003

[33] R.D. Fields, M.V. Lancaster, Am. Biotech. Lab. 11 (1993) 48-49.

[34] Systat Software, Inc, http://www.systat.com2006.

[35] K. Clauss, H. Bestian, Justus Liebigs Ann. Chem. 654 (1962) 8-19.

[36] R.C. Weast (Ed.), CRC Handbook of Chemistry and Physics, 69th Edition, CRCPress, Boca Raton, Florida, USA, 1989.

[37] R. Hamid, Y. Rotshteyn, L. Rabadi, R. Parikh, P. Bullock, Toxicol. In Vitro 18 (2004) 703-710.

[38] R. Leik, L. Zsolnai, G. Huttner, E.W. Neuse, H.H. Brintzinger, J. Organomet. Chem. 312 (1986) 177-182.

[39] M. Tacke, Lett. Drug Des. Discovery 5 (2008) 332-335.

[40] S. Eger, T.A. Immel, J. Claffey, H. Müller-Bunz, M. Tacke, U. Groth, T. Huhn, Inorg. Chem. (2010) 1292-1294. 